\title{
Pengaruh Pemberian Probiotik pada Level Protein Pakan Berbeda Terhadap Perlemakan Ayam Kampung
}

\author{
Influence of Probiotic on Different Level Protein Feed on fatty Native Chicken \\ Mubarak, P. R, L. D. Mahfudz, dan D. Sunarti \\ Fakultas Peternakan dan Pertanian, Universitas Diponegoro \\ Jalan Kampus drh. R. Soejono Kusumowardojo, Tembalang, Semarang, 50275 \\ Corresponding e-mail: puterarezekim@yahoo.com
}

\begin{abstract}
This study was to determine the effect of probiotics and protein level of feed on fat deposit of chicken. The material used were 3 weeks old chickens as many as 120 birds average initial weight of $149.11 \pm 7.25 \mathrm{~g}$ with a coefficient of variant (CV 13.45\%). The rations used were commercial broiler chicken for 3 weeks. experimental design was factorial ( $3 \times 2$ ) design. First factor was level probiotic as follows : $\mathrm{L} 1=0 \mathrm{ml} \times 107 \mathrm{cfu} / \mathrm{ml}, \mathrm{L} 2=$ $1.25 \mathrm{ml} \times 107 \mathrm{cfu} / \mathrm{ml}$ and L3 $=2.5 \times 107 \mathrm{cfu} / \mathrm{ml}$. Second factor was protein level as follows : $\mathrm{P} 1=18 \%$ and $16 \%$ for stater and $\mathrm{P} 2=16 \%$ and $14 \%$ for finisher. The combination of treatments were $=\mathrm{L} 1 \mathrm{P} 1, \mathrm{~L} 1 \mathrm{P} 2, \mathrm{~L} 2 \mathrm{P} 1, \mathrm{~L} 2 \mathrm{P} 2$ and L3P1, L3P2. The parameters examined were feed comsumption energy comsumption, meat fat mass and body weight gain. The results showed that there were no interaction between protein level and probiotic on all parameters. The protein level $18 \%$ was significantly $(\mathrm{P}<0.05)$ increased feed comsumption, energy comsumption meat fat mass and body weight gain. Conclusion of using protein level $18 \%$ and $16 \%$ was better than $16 \%$ and $14 \%$.
\end{abstract}

Key words: probiotics, feed protein level, fat, native chicken

\begin{abstract}
ABSTRAK
Penelitian ini untuk mengetahui pengaruh probiotik dan tingkat protein pakan terhadap deposit lemak ayam. Bahan yang digunakan adalah ayam berumur 3 minggu sebanyak 120 ekor dengan berat awal rata-rata 149,11 \pm $7,25 \mathrm{~g}$ dengan koefisien varian (CV 13,45\%). Ransum yang digunakan adalah ayam broiler komersial umur 3 minggu. Desain eksperimental adalah faktorial $(3 \times 2)$. Faktor pertama adalah kadar probiotik sebagai berikut: $\mathrm{L} 1=0 \mathrm{ml} \times 107 \mathrm{cfu} / \mathrm{ml}, \mathrm{L} 2=1,25 \mathrm{ml} \times 107 \mathrm{cfu} / \mathrm{ml}$ dan L3 $=2,5 \times 107 \mathrm{cfu} / \mathrm{ml}$. Faktor kedua adalah tingkat protein sebagai berikut: $\mathrm{P} 1=18 \%$ dan $16 \%$ untuk stater dan $\mathrm{P} 2=16 \%$ dan $14 \%$ untuk finisher. Kombinasi perlakuan adalah $=\mathrm{L} 1 \mathrm{P} 1, \mathrm{~L} 1 \mathrm{P} 2, \mathrm{~L} 2 \mathrm{P} 1, \mathrm{~L} 2 \mathrm{P} 2$ dan L3P1, L3P2. Parameter yang diteliti adalah konsumsi energi konsumsi, massa lemak daging dan pertambahan bobot badan. Hasil penelitian menunjukkan bahwa tidak ada interaksi antara kadar protein dan probiotik pada semua parameter. Tingkat protein $18 \%$ secara signifikan ( $\mathrm{P}$ $<0,05)$ meningkatkan konsumsi pakan, konsumsi energi massa lemak daging dan pertambahan berat badan. Kesimpulan menggunakan tingkat protein $18 \%$ dan $16 \%$ lebih baik dari $16 \%$ dan $14 \%$.
\end{abstract}

Kata kunci : probiotik, level protein pakan, lemak, ayam kampung

\section{PENDAHULUAN}

Ayam kampung merupakan ayam lokal Indonesia yang kehidupannya sudah dikenal dekat dengan masyarakat, ayam kampung disebut juga dengan ayam buras (bukan ras) atau ayam sayur. Potensinya patut dikembangkan untuk meningkatkan gizi masyarakat serta mendapatkan keluarga. Ayam kampung mempunyai kelebihan pada daya adaptasi tinggi karena mampu menyesuaikan diri dengan berbagai situasi.
Pemeliharaan ayam kampung masih banyak menggunakan pola semi intensif, di siang hari ayam diumbar dan kemudian di malam hari ayam dimasukkan ke kandang sehingga produktivitas ayam tidak maksimal. Kebutuhan protein pakan ayam kampung belum jelas standarnya berbeda dengan standar kebutuhan protein ayam ras. Penanggulangan hal tersebut dilakukan perbaikan pola pakan dengan cara memperbaiki protein pakan dan penambahan probiotik. 
Pemberian probiotik dapat memberiakan pengaruh positif pada ternak, karena dapat meningkatkan kecernaan pakan dan efisiensi pakan. Peran probiotik dapat meningkatkan keasaman pada saluran pencernaan ternak, dengan begitu bakteri pathogen tidak mampu bertahan pada lingkungan yang asam sehingga protein yang tercerna dapat terserap oleh usus dengan baik. Mengingat harga protein pakan yang mahal sehingga dilakukan kombinasi level protein pakan dengan probiotik diharapkan dapat menekan biaya produksi dan efisiensi penyerapan protein pakan pada ternak.

Penelitian ini bertujuan untuk mengetahui perlemakan ayam kampung akibat pemberian probiotik dengan level protein pakan berbeda pada ayam kampung terhadap konsumsi ransum, massa lemak daging, pertambahan bobot badan komulatif dan konsumsi energi. Diharapkan dapat memberikan manfaat kepada peternak maupun kalayak umum pada perlemakan ayam kampung akibat pemberian probiotik dengan level protein pakan berbeda.

\section{MATERI DAN METODE}

Materi yang digunakan pada penelitian ini adalah ayam kampung umur 3 minggu sebanyak 120 ekor dengan rata-rata bobot awal yakni $149.11 \pm 7,25 \mathrm{~g}$ dengan koefisien varian (CV 13.45).Bahan pakan dan kandungan nutrisi untuk penyusun pakan berupa jagung, bekatul, bungkil kedelai, PMM, premix dan probiotik. Pakan berbentuk crumble pada fase starter, maupun saat finisher. Komposisi dan kandungan nutrisi pakan penelitian periode starter dan finisher dapat dilihat di Tabel 1 dan Tabel 2.Kandang yang digunakan bertipe cage dengan lantai wire untuk pemeliharaan.

Tabel 1. Komposisi pakan dengan kadar protein berbeda

\begin{tabular}{|c|c|c|c|c|c|c|}
\hline \multirow[t]{2}{*}{ Komposisi Pakan } & \multicolumn{6}{|c|}{ Perlakuan Petama P1 (18\%) dan P2 (16\%) } \\
\hline & L1P1 & L2P1 & L3P1 & L1P2 & $\mathrm{L} 2 \mathrm{P} 2$ & L3P2 \\
\hline Bahan pakan & & & -----\%"-- & , & , & \\
\hline Jagung & 50,00 & 50,00 & 50,00 & 52,50 & 52,50 & 52,50 \\
\hline Bekatul & 22,00 & 22,00 & 22,00 & 24,00 & 24,00 & 24,00 \\
\hline Bungkil kedelai & 13,00 & 13,00 & 13,00 & 10,00 & 10,00 & 10,00 \\
\hline PMM & 13,00 & 13,00 & 13,00 & 11,00 & 11,00 & 11,00 \\
\hline $\mathrm{CaCO} 3$ & 1,00 & 1,00 & 1,00 & 1,50 & 1,50 & 1,50 \\
\hline Premix & 0,50 & 0,50 & 0,50 & 0,50 & 0,50 & 0,50 \\
\hline Lisin & 0,20 & 0,20 & 0,20 & 0,20 & 0,20 & 0,20 \\
\hline Metionin & 0,30 & 0,30 & 0,30 & 0,30 & 0,30 & 0,30 \\
\hline Total & 100 & 100 & 100 & 100 & 100 & 100 \\
\hline Komposisi Nutrisi & & & - & & (- & ----- \\
\hline $\mathrm{ME}(\mathrm{kkal} / \mathrm{kg})$ & 2937,68 & 2937,68 & 2937,68 & 2930,61 & 2930,61 & 2930,61 \\
\hline PK $(\%)$ & 18,49 & 18,49 & 18,49 & 16,55 & 16,55 & 16,55 \\
\hline LK $(\%)$ & 5,92 & 5,92 & 5,92 & 5,79 & 5,79 & 5,79 \\
\hline SK $(\%)$ & 6,51 & 6,51 & 6,51 & 6,53 & 6,53 & 6,53 \\
\hline $\mathrm{Ca}(\%)$ & 1,04 & 1,04 & 1,04 & 1,07 & 1,07 & 1,07 \\
\hline P $(\%)$ & 0,95 & 0,95 & 0,95 & 0,90 & 0,90 & 0,90 \\
\hline Lisin $(\%)$ & 1,31 & 1,31 & 1,31 & 1,17 & 1,17 & 1,17 \\
\hline Metionin(\%) & 0,68 & 0,68 & 0,68 & 0,65 & 0,65 & 0,65 \\
\hline
\end{tabular}

\section{Rancangan Penelitian}

Penelitian dilakukan melalui 2 tahap, yaitu tahap persiapan dan pelaksanaan. Tahap persiapan penelitian ada 2 macam, yaitu persiapan umum dan persiapan teknis. Tahap pelaksanaan dibagi menjadi 2 periode yaitu tahap pendahuluan dan perlakuan.
Tahap pendahuluan merupakan tahap dimana ayam belum diberikan perlakuan. Dilakukan adaptasi selama 3 minggu,dilakukan penimbangan untuk mendapatkan keseragaman bobot badan, kemudian secara acak dipindahkan ke dalam 24 unit percobaan untuk diberikan 
perlakuan. Tahap perlakuan dimulai saat ayam umur 21 hari dan berakhir pada umur ayam 90 hari.

Pemberian ransum sesuai kebutuhan dan air minum diberikan ad libitum sedangkan pemberian probiotik dilakukan dengan cara force feeding dimana pemberian probiotik lewat air minumdengan bantuan alat suntik sehingga memudahkan dalam pendeposisian didalam tembolok.

\section{Rancangan Penelitian}

Penelitian dilakukan melalui 2 tahap, yaitu tahap persiapan dan pelaksanaan. Tahap persiapan penelitian ada 2 macam, yaitu persiapan umum dan persiapan teknis. Tahap pelaksanaan dibagi menjadi 2 periode yaitu tahap pendahuluan dan perlakuan. Tahap pendahuluan merupakan tahap dimana ayam belum diberikan perlakuan. Dilakukan adaptasi selama 3 minggu,dilakukan penimbangan untuk mendapatkan keseragaman bobot badan, kemudian secara acak dipindahkan ke dalam 24 unit percobaan untuk diberikan perlakuan. Tahap perlakuan dimulai saat ayam umur 21 hari dan berakhir pada umur ayam 90 hari.
Pemberian ransum sesuai kebutuhan dan air minum diberikan ad libitumdan pemberian probiotik dilakukan dengan cara force feeding dimana pemberian probiotik lewat air minumdengan bantuan alat suntik sehingga memudahkan dalam pendeposisian didalam tembolok.

\section{Perlakuan Penelitian}

Rancangan yang digunakan yakni rancangan acak lengkap pola faktorial $(3 \mathrm{x}$ 2) diulang 4 kali, sehingga terdapat 24 unit perlakuan. Setiap unit perlakuan terdiri dari 5 ekor anak ayam. Perlakuan ada dua kombinasi perlakuan di level protein starter P1 (18\%) P2 (16\%).

\section{Parameter penelitian meliputi sebagai berikut :}

1. Konsumsi ransum = Sebagai acuan kebutuhan ransum ayam selama periode perlakuan (Rasaf, 1997) Konsumsi ransum (g/ekor/hari) = Ransum yang diberikan $(\mathrm{g})$ - Sisa ransum $(\mathrm{g})$

2. Massa lemak daging = dengan cara melakukan analisis lemak. Kemudian menghitung massa lemak daging dengan rumus: Massa lemak daging $=$ Kadar Lemak X Bobot Daging

Tabel 2. Komposisi pakan dengan kadar protein berbeda

\begin{tabular}{|c|c|c|c|c|c|c|}
\hline \multirow{2}{*}{ Komposisi Pakan } & \multicolumn{6}{|c|}{ Perlakuan Kedua P1 (16\%) dan P2 (14\%) } \\
\hline & L1P1 & L2P1 & L3P1 & L1P2 & $\mathrm{L} 2 \mathrm{P} 2$ & L3P2 \\
\hline Bahan Pakan & & & & (0-----י & & ---- \\
\hline Jagung & 52,50 & 52,50 & 52,50 & 55,00 & 55,00 & 55,00 \\
\hline Bekatul & 24,00 & 24,00 & 24,00 & 25,00 & 25,00 & 25,00 \\
\hline Bungkil Kedelai & 10,00 & 10,00 & 10,00 & 9,00 & 9,00 & 9,00 \\
\hline PMM & 11,00 & 11,00 & 11,00 & 8,00 & 8,00 & 8,00 \\
\hline $\mathrm{CaCO} 3$ & 1,50 & 1,50 & 1,50 & 2,00 & 2,00 & 2,00 \\
\hline Premix & 0,50 & 0,50 & 0,50 & 0,50 & 0,50 & 0,50 \\
\hline Lisin & 0,20 & 0,20 & 0,20 & 0,20 & 0,20 & 0,20 \\
\hline Metionin & 0,30 & 0,30 & 0,30 & 0,30 & 0,30 & 0,30 \\
\hline Total & 100 & 100 & 100 & 100 & 100 & 100 \\
\hline Komposisi Nutrisi & & & 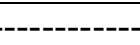 & $\%$ & ------- & ---- \\
\hline ME (kkal/kg) & 2930,61 & 2930,61 & 2930,61 & 2926,35 & 2926,35 & 2926,35 \\
\hline PK $(\%)$ & 16,55 & 16,55 & 16,55 & 14,86 & 14,86 & 14,86 \\
\hline LK $(\%)$ & 5,79 & 5,79 & 5,79 & 5,61 & 5,61 & 5,61 \\
\hline SK $(\%)$ & 6,53 & 6,53 & 6,53 & 6,51 & 6,51 & 6,51 \\
\hline $\mathrm{Ca}(\%)$ & 1,07 & 1,07 & 1,07 & 1,06 & 1,06 & 1,06 \\
\hline P (\%) & 0,90 & 0,90 & 0,90 & 0,80 & 0,80 & 0,80 \\
\hline Lisin $(\%)$ & 1,17 & 1,17 & 1,17 & 1,04 & 1,04 & 1,04 \\
\hline Metionin (\%) & 0,65 & 0,65 & 0,65 & 0,62 & 0,62 & 0,62 \\
\hline
\end{tabular}


3. Pertumbuhan bobot badan kumulatif $=$ dengan menimbang ayam diawal dan diakhir penelitian. Rumus yang digunakan adalah Bobot badan akhir (g) - Bobot badan awal (g)

4. Konsumsi energi $=$ Energi digunakan oleh ayam untuk kebutuhan hidup pokok. Kebutuhan energi untuk unggas dinyatakan dengan energi termetabolis (ME). Energi termetabolis diperoleh dengan mengurangi energi ransum (GE) dengan energi ekskreta (feses dan urine). Dari sejumlah energi tersebut tidak seluruhnya dapat digunakan langsung tetapi masih ada yang hilang dalam bentuk panas (heat increment) selama proses metabolisme, sehingga yang tinggal yaitu energi netto.

\section{HASIL DAN PEMBAHASAN}

Hasil nilai rerata konsumsi ransum, massa lemak daging, bobot badan komulatif dan konsumsi energi ayam kampung umur 7 minggu dapat dilihat pada Tabel 2. Tidak terdapat interaksi $(\mathrm{P}>0,05)$ akibat pemberian Probiotik pada level protein pakan terhadap semua parameter. Level protein pakan berpengaruh nyata $(\mathrm{P}<0,05)$ terhadap semua parameter dan pemberian probiotik tidak berpengaruh nyata.

\section{Konsumsi Ransum}

Rerata konsumsi ransum pada perlakuan level protein pakan 18/16 \% sebesar 44,68 gram dan perlakuan level protein pakan 16/14\% sebesar 40,13 gram. Akibat level protein pakan memberikan pengaruh nyata terhadap konsumsi ransum ayam kampung. Semakin meningkat konsumsi ransum berbanding lurus dengan meningkatnya level protein pakan. Pertumbuhan ayam salah satunya didukung dari kecukupan protein pakan. Tercukupinya kebutuhan protein pakan di awal pertumbuhan berbanding lurus meningkat pertambahan bobot badan harian. Menurut Scaible (1980) bahwa kandungan protein yang tinggi tidak akan menurunkan konsumsi ransum, sedangkan perubahan konsumsi ransum akan mempengaruhi terhadap produktivitasnya, yaitu dipengaruhi oleh perubahan kandungan protein ransum yang dikonsumsi.

Tabel 3. Pengaruh pemberian probiotik pada level protein pakan berbeda terhadap konsumsi ransum, massa lemak daging, pertambahan bobot badan kumulatif, konsumsi energi pada ayam kampung

\begin{tabular}{|c|c|c|c|c|}
\hline Faktor & $\begin{array}{l}\text { Konsumsi } \\
\text { Ransum }\end{array}$ & $\begin{array}{c}\text { Massa Lemak } \\
\text { Daging }\end{array}$ & $\begin{array}{c}\text { PBB } \\
\text { Komulatif }\end{array}$ & $\begin{array}{l}\text { Konsumsi } \\
\text { Energi }\end{array}$ \\
\hline & \multicolumn{4}{|c|}{---------------(g)----------------------(\%)----------(g/ekor)-- } \\
\hline L1 & 43,70 & 2,07 & 429,77 & 119,03 \\
\hline L2 & 41,87 & 1,61 & 432,63 & 122,32 \\
\hline L3 & 41,65 & 1,65 & 448,47 & 112,13 \\
\hline Signifikansi & ns & ns & ns & ns \\
\hline P1 & $44,68^{\mathrm{a}}$ & $2,11^{\mathrm{a}}$ & $465,68^{\mathrm{a}}$ & $123,43^{\mathrm{a}}$ \\
\hline $\mathrm{P} 2$ & $40,13^{\mathrm{b}}$ & $1,45^{\mathrm{b}}$ & $408,24^{\mathrm{b}}$ & $112,23^{b}$ \\
\hline Signifikansi & $*$ & $*$ & $*$ & $*$ \\
\hline \multicolumn{5}{|l|}{ Interaksi } \\
\hline $\mathrm{P} \times \mathrm{L}$ & $\mathrm{ns}$ & ns & ns & ns \\
\hline Rataan Populasi & 42,28 & 1,98 & 436,96 & 117,83 \\
\hline
\end{tabular}


Perlakuan level protein pakan berpengaruh nyata terhadap konsumsi ransum diduga karena kandungan protein pakan semakin tinggi akan mempercepat deposisi daging dan volume tubuh ternak, sehingga berbanding lurus dengan tingkat konsumsi ransum yang tinggi dibandingakan dengan perlakuan level proten pakan yang rendah. Konsumsi ransum pada perlakuan level protein $18 \%$ lebih tinggi dibandingkan dengan level protein $16 \%$. Hal ini sesuai dengan pendapat Widjastuti dan Garnida (2005) bahwa ayam mengkonsumsi ransum guna memenuhi kebutuhan energinya, bila telah terpenuhi maka ayam akan berhenti makan. Scaible (1980) menyatakan bahwa tutjuan utama unggas mengkonsumsi ransum cenderung untuk mencukupi kebutuhan energinya sehingga konsumsi ransum berhubungan erat dengan tingkat energi dalam ransum.

Pemberian probiotik tidak berpengaruh nyata $(\mathrm{P}<0,05) \quad$ terhadap konsumsi ransum dimungkinkan jumlah probiotik yang terdeposisikan di saluran pencernaan ayam relative sedikit dibandingkan jumlah bakteri pathogen, sehingga peran probiotik tidak mampu meningkatkan kecernaan protein pakan. Menurut pendapatnya Sindu (2009) bahwa tidak ada perbedaan yang signifikan pada berat badan dan konversi pakan ayam yang mendapat tambahan probiotik pada ransumnya dengan kontrol yang tidak mendapat probiotik.Menurut Jin et al. (1998) dapat disebabkan oleh perbedaan spesies/strain mikroba yang digunakan atau metode yang digunakan dalam menyiapkan suplemen probiotik.

\section{Massa Lemak Daging}

Hasil penelitian Singgih dan Ning (2013) bahwa rataan hasil penelitian pemberian pakan fungsional terhadap kadar lemak ayam broiler adalah antara 1,81\% sampai 2,31\%. Menurut Chan et al. (1995) keseluruhan lemak daging pada daging ayam kondisi mentah rata-rata $2,1 \%$. Supadmo (1997) menyatakan bahwa, terdapat perbedaan yang nyata kandungan lemak daging umur 7 minggu antara ayam jantan $(2,68 \%)$ dan ayam betina $(2,86 \%)$.

Hasil penelitian ini tidak menunjukkan pengaruh nyata akbiat pemberian probiotik terhadap massa lemak daging ayam kampung umur 7 minggu diduga probiotik sudah mati sebelum masuk kesaluran pencernaan. Menurut Collins (1999) bahwa peran probiotik mampu mempengaruhi aktivitas enzim dan sebagai konsekuensinya membantu menurunkan kadar lemak darah tetapi belum mampu menurunkan kadar lemak daging. Menurut Daud (2007) bahwa penambahan probiotik dalam ransum ayam pedaging tidak menunjukkan hasil yang signifikan terhadap kadar lemak daging yang diperoleh. Owings et al. (1990) bahwa beberapa penelitian tentang probiotik tidak selalu mendapatkan hasil yang positif. Perbedaan hasil penelitian tersebut disebabkan oleh beberapa hal diantaranya perbedaan jenis atau strain bakteri dalam probiotik yang digunakan, dosis pemberian pada ternak, tingkat ketahanan bakteri terhadap kondisi yang ekstrim baik dalam saluran pencernaan ternak maupun lingkungan penyimpanan. Penelitian ini menunjukkan bahwa penggunaan pakan fungsional dalam ransum yang mengandung probiotik tidak menyebabkan perbedaan yang nyata terhadap kadar lemak daging ayam kampung.

\section{Pertambahan Bobot Badan Kumulatif}

Pertambahan bobot badan kumulatif berpengaruh nyata $(\mathrm{P}<0,05)$ akibat pemberian level protein pakan. Rerata pertambahan bobot badan pada level protein pakan 18/16\% sebesar 465,68 g sedangkan pada level protein pakan $16 / 14 \%$ sebesar 408,24 g. Pertambahan bobot badan kumulatif signifikan sejalan konsumsi ransum yang signifikan. Semakin tinggi konsumsi ransum sejalan dengan semakin tinggi bobot badan komulatif.Hal ini sesuai dengan pendapat Yamin (2002) bahwa untuk menghasilkan bobot badan maksimal maka sangat perlu diperhatikan kualitas dan kuantitas ransum. Ransum tersebut harus mengandung zat makanan dalam keadaan cukup dan seimbang sehingga dapat 
menunjang pertumbuhan maksimal. Peran protein pada ternak salah satunya dalam pembentukan daging, pengganti sel-sel yang rusak dan faktor pendukung proses pertumbuhan.

Hal ini sesuai pendapat Hutapea (2003) yang menyatakan bahwa peningkatan konsumsi protein kasar dan energi akan memberikan peningkatan pertumbuhan yang terukur dari kenaikan bobot badan yang lebih tinggi. Scott et al. (1982) menyatakan bahwa pertumbuhan unggas dipengaruhi oleh jumlah ransum yang dikonsumsi. Hasil penelitian didukung hasil penelitian Dewi et al. (2009) bahwa ayam kampung diberi ransum mengandung imbangan energi dan protein lebih tinggi menghasilkan berat badan lebih tinggi secara nyata dibanding ransum mengandung imbangan energi dan protein lebih rendah pada umur 8 minggu.

Hal ini sesuai pendapat Wahju (1992) yang menyatakan bahwa tingkat protein ransum dapat mempengaruhi nilai pertambahan bobot badan dan konversi ransum. Sidadolog dan Yuwanta (2010) menyatakan bahwa hubungan antara konsumsi ransum dan pertambahan berat badan ditentukan oleh konversi pakan, ransum dengan imbangan protein energi rendah akan menghasilkan konversi ransum yang lebih rendah.

Pengaruh pemberian probiotik tidak berpengaruh nyata $(\mathrm{P}<0,05)$ terhadap pertambahan bobot badan kumulatif. Hal ini dapat disebabkan peran probiotik kurang aktif didalam saluran pencernaan sehingga tidak dapat meningkatkan kecernaan protein pakan. Menurut Novel dan Safitri (2009) bahwa bakteri probiotik mampu mereduksi $\mathrm{pH}$ di usus, melancarkan pencernaan dengan memproduksi beberapa enzim pencernaan dan vitamin, memproduksi substansi antibakteri, misalnya asam organik, bacteriosin, $\mathrm{H} 2 \mathrm{O} 2$ dan zat-zat lainnya. Keuntungan dari penggunaan probiotik adalah memperbaiki pertumbuhan ternak, efisiensi pakan maupun kesehatan ternak (Gunawan dan Sunandari, 2003).

\section{Konsumsi Energi}

Rerata konsumsi energi pada perlakuan level protein pakan 18/16\% sebesar 123,43 g dan perlakuan level protein pakan 16/14\% sebesar 112,23 g. Akibat level protein pakan memberikan pengaruh nyata terhadap konsumsi energi ayam kampung. Sejalan dengan penelitianya Penelitian Candrawati (1999) mendapatkan bahwa kebutuhan energi untuk hidup pokok pada ayam kampung umur $0-8$ minggu adalah: $\quad 103,96 \mathrm{kkal} \quad \mathrm{ME} / \mathrm{W} 0,75 / \mathrm{hari}$, sedangkan Asnawi (1997) mendapatkan 127,75 kkal ME/W0,75/hari, pada ayam kampung umur 0 -8 minggu. Sturkie (1976) menyatakan bahwa kebutuhan energi untuk pokok dipengaruhi oleh: bangsa ayam (varietas) dan lingkungan.Kebutuhan energi untuk pertumbuhan dihitung dengan cara menghitung jumlah energi termetabolis untuk meningkatkan $1 \mathrm{~g}$ berat badan. Protein dibutuhkan oleh ayam untuk kebutuhan hidup pokok dan kebutuhan untuk pertumbuhan.

Hasil penelitian konsumsi nergi tidak berpengaruh signifikan akibat pemberian probiotik terhadap konsumsi energi ayam kampung umur 7 minggu di duga dipengaruhi kondisi iklim lingkuangan yang berubah-ubah (pancaroba).

Menurut pendapatnya Mountzouris et al. (2007) bahwa faktor yang mempengaruhi penggunaan probiotik pada ternak salah satunya dipengaruhi oleh jenis bakteri dan ketahanan hidupnya, metode pemberian pada ternak, frekuensi pemberian, pakan, umur unggas, kebersihan lingkungan dan stres akibat lingkungan (seperti suhu, kepadatan). Pendapatnya Kompiang dan Supriyati (2001) bahwa secara naluri ungags akan lebih mencukupi kebutuhan energi dibandingkan kebutuhan protein. Selain keseimbangan kandungan energi dan protein, imbangan asam amino, kadar vitamin maupun mineral juga mempunyai pengaruh terhadap konsumsi pakan. 


\section{KESIMPULAN}

Level protein $18 \%$ memberikan hasil yang lebih baik pada komsumsi ransum, massa lemak daging, pertambahan bobot badan kumulatif, dan komsumsi energi. Pada probiotik hasilnya sama.

\section{DAFTAR PUSTAKA}

Asnawi.1997. Kinerja Pertumbuhan dan Fisiologi Ayam Kampung dan Hasil Persilangannya dengan Ayam Ras Tipe Pedaging" (Thesis). Institut Pertanian Bogor. Bogor.

Candrawati, D. P. M. A. 1999. Pendugaan Kebutuhan Energi dan Protein Ayam Kampung Umur 0-8 minggu (tesis). Institut Pertanian Bogor. Bogor.

Chan, W., Brown W.C, Lee S. M and Buss D. H, 1995. Meat, Poultry and Game. Di dalam: Supplement to Mc Cane \& Widdowson's. The Composition of Foods. London: Published by The Royal society of Chemistry, Cambridge anf Ministry of Agriculture, Fisheries and Food.

Collins, G.R and Gibson, 1999. Prebiotic, probiotic, and synbiotic: approaches for modulating the microbial ecology of the gut. J. Anim. Sci. Nutr, 69: 1052S-1057S.

Daud, M., G. P Wiranda dan I. P. Kompiang. 2007. Persentase dan kualitas karkas ayam pedaging yang diberi probiotik dan prebiotik dalam ransum. JITV. 12 (3) ; 167-174.

Gunawan dan M. M. S. Sundari. 2003. Pengaruh Penggunaan Probiotik dalam Ransum terhadap
Produktivitas Ayam.Wartazoa. 13 (3): 92-98.

Kompiang, I. P. dan Supriyati. 2001. Pengaruh cara pemberian pakan dan ampas sagu terfermentasi terhadap kinerja ayam pedaging. J. Ilmu Ternak Vet. 6 (1):14-20.

Mountzouris, K. C., P. Tsirtsikos, E. Kalamora, S. Nitsch, G. Schatzmayr, and K. Fegeros. 2007. Evaluation of The Efficacy of A Probiotic Containing Lactobacillus, Bifidobacterium, Enterococcus, and Pediococcus Strains in Promoting Broiler Performance and Modulating Cecal Microflora Composition and Metabolic Activities. Poultry Science $86: 309$ $-317$.

Owings, W. J., D. L. Reynolds, R. J. Hasiak and R. Ferket. 1990. Influence of dietary supplementation with Streptococcus faecium M-74 on broiler body weight, feed conversion, carcass characteristics and intestinal microbial colonization. Poult. Sci, 69: 12571264.

Rasyaf, M. 1997. Makanan Ayam Broiler. Cetakan Pertama. Penerbit Kanisius. Yogyakarta.

Scott, M. L., M.C, Nesheim and R.J.Young. 1982. Nutritions of The Chickens $3^{\text {rd }}$. Second Ed. M. L. Scott and Associates Ithaca, New York.

Sindu, A. 2009. Pengaruh pemberian probiotik temban, biovet dan biolacta kedalam air minum terhadap peforman ayam broiler. Jurnal Sains dan Teknologi Indonesia, 11 (3) ;145-150. 
Singgih, S. S, dan I. Ning. 2013. Penggunaan Level Protein Pakan fungsional terhadap kadar lemak dan protein daging ayam broiler. JIP, 1(1): 289298.

Sturkei, P. D. 1976. Avian Physiology. Third Edition. Heidelberg Berlin.

Supadmo. 1997. Pengaruh sumber khitin dan prekursor karnitin serta minyak ikan lemuru terhadap kadar lemak dan kolesterol serta asam lemak omega 3 ayam broiler. Disertasi. Program Pasca Sarjana. Institut Pertanian Bogor, Bogor.

Yamin, M., 2002. Pengaruh tingkat protein ransum terhadap komsumsi, pertambahan bobot badan dan IOFC ayam buras umur 0-18 minggu. Jurnal Agroland. 9 (3): 229-235 